\title{
HLA-DR Binding Prediction and Experimental Evaluation of T-Cell Epitopes of Mycolyl Transferase 85B (Ag85B), a Major Secreted Antigen of Mycobacterium tuberculosis
}

\author{
Abu S. Mustafa ${ }^{a}$ Adnan T. Abal $^{\mathrm{b}, \mathrm{c}}$ Fatma Shaban ${ }^{\mathrm{a}}$ \\ Abdulsalam M. El-Shamyc Hanady A. Amoudy ${ }^{\mathrm{C}}$ \\ Departments of a Microbiology and ${ }^{\mathrm{b}}$ Medicine, Faculty of Medicine, Kuwait University, and \\ ${ }^{c}$ Chest Diseases Hospital, Kuwait
}

\section{Key Words}

Ag85B $\cdot$ HLA-DR binding prediction $\cdot$ Mycobacterium

tuberculosis $\cdot$ T-cell epitopes

\begin{abstract}
Objective: To identify T-cell epitopes of Ag85B by analysis of its sequence for prediction to bind HLA-DR alleles and evaluate the predicted peptides for recognition by $T$ cells in antigen-induced proliferation assays. Materials/ Subjects and Methods: The complete sequence of Ag85B was analyzed for HLA-DR binding prediction to 51 HLADR alleles by using a virtual matrix-based prediction program (ProPred). Synthetic peptides covering the sequence of mature $A g 85 B$ were also analyzed for binding to HLA-DR alleles, and evaluated for recognition in antigen-induced proliferation assays with Ag85B-specific Tcell lines established from the peripheral blood mononuclear cells of $10 \mathrm{HLA}$-DR-heterogeneous tuberculosis patients. Results: The ProPred analysis of the full-length Ag85B (325 aa), signal peptide (40 aa) and the mature protein (285 aa) predicted their binding to 100,76 and $98 \%$ of the 51 HLA-DR alleles, respectively. The analysis of 31 synthetic peptides for binding to HLA-DR alleles showed that 4 of them could bind $>50 \%$ HLA-DR alleles, and were considered promiscuous. Testing of Ag85Bspecific T-cell lines with synthetic peptides showed that
\end{abstract}

all of the T-cell lines responded to one or more peptides of $\mathrm{Ag} 85 \mathrm{~B}$, and 9 of the 10 cell lines responded to one or more of the four peptides considered promiscuous for binding to HLA-DR alleles. Conclusion: The ProPred program was useful in predicting the HLA-DR alleles binding regions of Ag85B and identifying the promiscuous peptides recognized by $T$ cells.

Copyright $(2005$ S. Karger AG, Basel

\section{Introduction}

Tuberculosis (TB) is a major health problem of global concern. The recent estimates suggest that about one third of the world population is infected with Mycobacterium tuberculosis, 8-10 million people develop active disease and 2 million people die of TB each year [1]. In addition to being an international problem, TB is also a serious infectious disease problem in the countries of the Gulf Region, including Kuwait [2]. The effective control of TB is dependent on the availability of universally efficacious vaccines and reagents for specific diagnosis [3]. The use of currently available vaccine, i.e. $M$. bovis BCG, and the diagnostic reagent, i.e. purified protein derivative of $M$. tuberculosis, has not been successful in reducing the worldwide morbidity and mortality of TB. Thus, there is a need to identify antigens/peptides of $M$. tuberculosis

\section{KARGER}

Fax +4161306 1234 E-Mail karger@karger.ch www.karger.com
(C) $2005 \mathrm{~S}$. Karger AG, Basel

1011-7571/05/0143-0140\$22.00/0

Accessible online at:

www.karger.com/mpp
Prof. Abu Salim Mustafa

Department of Microbiology, Faculty of Medicine

Kuwait University, PO Box 24923

13110 Safat (Kuwait)

Tel. +965 5312300/ext. 6505, Fax +965 5332719, E-Mail abusalim@hsc.edu.kw 
which will be useful as subunit vaccines and/or reagents for specific diagnosis.

In the past, to identify mycobacterial antigens of diagnostic and/or vaccine potential, proteins obtained through biochemical purification methods or recombinant DNA techniques have been used to test for T-cell reactivity [3-5]. However, the use of these techniques to obtain protein antigens in large quantities, which is required for human applications, is a challenging task with high costs. In addition, mycobacterial antigens are usually expressed in heterologous hosts like Escherichia coli, and the purification of recombinant mycobacterial proteins, free of $E$. coli components, can be quite difficult [6, 7]. Furthermore, complete antigens may have both species-specific as well as cross-reactive, and helper as well as suppressor T-cell epitopes [8-10], thus limiting their potential in specific diagnosis and/or development of new vaccines.

The recognition of antigens by $\mathrm{T}$ cells requires processing into small peptides by antigen-presenting cells (APC) and association with major histocompatibility complex (MHC) molecules. The peptides recognized by $\mathrm{T}$ cells are usually of small size, i.e. $<18$ aa [11], and can be synthesized chemically in large quantities and purified. The potentials of synthetic peptides to identify T-cell epitopes and their usefulness for diagnostic and vaccine applications have been demonstrated in recent studies [12-17]. However, in most of these studies, overlapping synthetic peptides covering the entire sequence of a protein were used to identify the peptides recognized by $\mathrm{T}$ cells [1216]. Since, usually, a fraction of peptides of large size proteins is recognized by T cells [18-20], the overlapping peptide approach becomes quite costly if several largesize proteins are to be tested for T-cell reactivity. An alternative approach could be to analyze protein sequences to predict MHC binding regions [21], and then test peptides corresponding to these regions for T-cell reactivity. Such an approach drastically reduces the numbers of peptides to be tested [21], and thus the cost to identify T-cell epitopes.

In the past, several prediction programs have been proposed to identify peptides capable of binding to human MHC molecules, i.e. HLA [22-25]. More recently, a virtual matrix-based prediction program (ProPred) was used to predict the binding of peptides to 51 HLA-DR alleles [26]. The aim of this study was to evaluate the usefulness of ProPred for the identification of T-cell epitopes of mycolyl transferase 85B (Ag85B, Rv1886c) a major secreted antigen of $M$. tuberculosis. In addition, the predicted HLA-DR binding regions were verified in antigen-induced proliferation assays using antigen-specific T-cell lines established from the peripheral blood mononuclear cells (PBMC) of TB patients.

\section{Materials and Methods}

ProPred Analysis for HLA-DR Binding Regions in Ag85B

HLA-DR binding propensities along the primary structures of Ag85B were detected using ProPred at a threshold value of 3.0. The ProPred is a graphical web tool for the prediction of MHC class II binding regions in antigenic protein sequences using the server (http://www.imtech.res.in/raghava/propred/) [26]. This server has been suggested to be a useful tool in locating the regions that can bind to a total of 51 HLA-DR alleles belonging to nine serological specificities encoded by DRB1 and DRB5 genes, i.e. HLA-DR1 (2 alleles), -DR3 (7 alleles), -DR4 (9 alleles), -DR7 (2 alleles), -DR8 (6 alleles), -DR1 1 (9 alleles), -DR13 (11 alleles), -DR15 (3 alleles) and -DR51 (2 alleles). The server performs analysis for each of these alleles independently and computes the binding strength of all the peptide regions.

\section{M. tuberculosis Antigens and Peptides}

The complex $M$. tuberculosis antigens used in this study were killed whole-cell, sonicate, culture filtrate and cell walls [27]. The Ag85B and the peptides corresponding to its sequence have been previously described [18].

\section{Study Subjects and Isolation of PBMC}

The study was approved by the Ethical Committee of the Faculty of Medicine, Kuwait University, Kuwait. Heparinized venous blood was collected from 10 pulmonary TB patients attending the Chest Diseases Hospital, Kuwait. PBMC were separated from the blood by density centrifugation according to standard procedures [19]. The cells were finally suspended in complete tissue culture medium [RPMI $1640+10 \%$ human $\mathrm{AB}$ serum + penicillin $(100 \mathrm{U} / \mathrm{ml})+\operatorname{streptomycin}(100 \mu \mathrm{g} / \mathrm{ml})+$ gentamycin $(40 \mu \mathrm{g} / \mathrm{ml})$ + fungizone $(2.5 \mu \mathrm{g} / \mathrm{ml})$ ] and counted with a Coulter counter (Coulter Electronics, Luton, UK).

\section{HLA-DR Typing of PBMC}

Genomic HLA-DR typing of PBMC was performed using sequence-specific primers in polymerase chain reaction as described previously [28]. In brief, a HLA-DR 'low resolution' kit containing the primers to type for DRB1, DRB3, DRB4 and DRB5 alleles was purchased form Dynal (Oslo, Norway) and used according to the manufacturer's instructions. The amplified products were analyzed by gel electrophoresis according to standard procedures [19]. The genotypes were identified from the size of the amplified products and serologically defined HLA-DR specificities were determined by following the guidelines provided by Dynal.

\section{Antigen-Induced Proliferation of PBMC}

Antigen-induced proliferation of $\mathrm{PBMC}$ was performed by standard procedures [29]. In brief, PBMC $\left(2 \times 10^{5}\right.$ cells/well $)$ suspended in $50 \mu \mathrm{l}$ complete tissue culture medium were seeded into 96well tissue culture plates (Nunc, Roskilde, Denmark). Antigen in $50 \mu \mathrm{l}$ of complete medium was added to the wells in triplicate to a final concentration of $5 \mu \mathrm{g} / \mathrm{ml}$. The final volume of the culture in the wells was adjusted to $200 \mu \mathrm{l}$. The plates were incubated at 
Table 1. The sequence regions of the full-length Ag85B protein predicted to bind HLA-DR alleles (numbers of alleles predicted to bind/numbers of alleles tested are given)

\begin{tabular}{llllllllllr}
\hline \multirow{2}{*}{$\begin{array}{l}\text { Sequence region } \\
\text { of Ag85B }\end{array}$} & \multicolumn{7}{l}{ ProPred prediction to bind HLA-DR alleles (genomic/serological) } \\
\cline { 2 - 10 } & $\mathrm{B} 1.1 / 1$ & $\mathrm{~B} 1.3 / 3$ & $\mathrm{~B} 1.4 / 4$ & $\mathrm{~B} 1.7 / 7$ & $\mathrm{~B} 1.8 / 8$ & $\mathrm{~B} 1.11 / 5$ & $\mathrm{~B} 1.13 / 6$ & $\mathrm{~B} 1.15 / 2$ & $\mathrm{~B} 5 / 51$ & total \\
\hline aa $4-19$ & $0 / 2$ & $0 / 7$ & $1 / 9$ & $0 / 2$ & $5 / 6$ & $8 / 9$ & $11 / 11$ & $1 / 3$ & $0 / 2$ & $26 / 51$ \\
aa 15-32 & $2 / 2$ & $7 / 7$ & $0 / 9$ & $2 / 2$ & $0 / 6$ & $1 / 9$ & $0 / 11$ & $0 / 3$ & $0 / 2$ & $12 / 51$ \\
aa 23-37 & $2 / 2$ & $0 / 7$ & $0 / 9$ & $0 / 2$ & $1 / 6$ & $3 / 9$ & $2 / 11$ & $2 / 3$ & $0 / 2$ & $10 / 51$ \\
aa 50-58 & $1 / 2$ & $1 / 7$ & $1 / 9$ & $2 / 2$ & $0 / 6$ & $1 / 9$ & $1 / 11$ & $0 / 3$ & $0 / 2$ & $7 / 51$ \\
aa 58-66 & $0 / 2$ & $7 / 7$ & $0 / 9$ & $0 / 2$ & $0 / 6$ & $1 / 9$ & $0 / 11$ & $0 / 3$ & $0 / 2$ & $8 / 51$ \\
aa 76-85 & $2 / 2$ & $6 / 7$ & $3 / 9$ & $0 / 2$ & $3 / 6$ & $8 / 9$ & $6 / 11$ & $3 / 3$ & $0 / 2$ & $31 / 51$ \\
aa 100-110 & $1 / 2$ & $2 / 7$ & $1 / 9$ & $2 / 2$ & $0 / 6$ & $4 / 9$ & $3 / 11$ & $1 / 3$ & $0 / 2$ & $14 / 51$ \\
aa 100-117 & $2 / 2$ & $3 / 7$ & $1 / 9$ & $2 / 2$ & $2 / 6$ & $5 / 9$ & $3 / 11$ & $3 / 3$ & $2 / 2$ & $23 / 51$ \\
aa 108-117 & $0 / 2$ & $1 / 7$ & $0 / 9$ & $0 / 2$ & $2 / 6$ & $1 / 9$ & $0 / 11$ & $2 / 3$ & $0 / 2$ & $6 / 51$ \\
aa 112-120 & $0 / 2$ & $0 / 7$ & $4 / 9$ & $0 / 2$ & $0 / 6$ & $3 / 9$ & $5 / 11$ & $0 / 3$ & $0 / 2$ & $12 / 51$ \\
aa 135-145 & $0 / 2$ & $0 / 7$ & $5 / 9$ & $1 / 2$ & $0 / 6$ & $0 / 9$ & $0 / 11$ & $1 / 3$ & $0 / 2$ & $7 / 51$ \\
aa 148-156 & $0 / 2$ & $1 / 7$ & $0 / 9$ & $0 / 2$ & $2 / 6$ & $2 / 9$ & $2 / 11$ & $0 / 3$ & $2 / 2$ & $9 / 51$ \\
aa 155-163 & $0 / 2$ & $0 / 7$ & $3 / 9$ & $2 / 2$ & $0 / 6$ & $0 / 9$ & $0 / 11$ & $0 / 3$ & $0 / 2$ & $5 / 51$ \\
aa 163-175 & $0 / 2$ & $3 / 7$ & $5 / 9$ & $2 / 2$ & $0 / 6$ & $1 / 9$ & $0 / 11$ & $0 / 3$ & $0 / 2$ & $11 / 51$ \\
aa 183-193 & $2 / 2$ & $1 / 7$ & $8 / 9$ & $2 / 2$ & $3 / 6$ & $6 / 9$ & $6 / 11$ & $3 / 3$ & $0 / 2$ & $31 / 51$ \\
aa 240-256 & $0 / 2$ & $0 / 7$ & $6 / 9$ & $0 / 2$ & $0 / 6$ & $8 / 9$ & $10 / 11$ & $2 / 3$ & $0 / 2$ & $26 / 51$ \\
aa 268-281 & $0 / 2$ & $7 / 7$ & $6 / 9$ & $2 / 2$ & $1 / 6$ & $6 / 9$ & $6 / 11$ & $3 / 3$ & $2 / 2$ & $33 / 51$ \\
aa 272-292 & $2 / 2$ & $0 / 7$ & $2 / 9$ & $0 / 2$ & $0 / 6$ & $3 / 9$ & $2 / 11$ & $0 / 3$ & $0 / 2$ & $9 / 51$ \\
aa 293-304 & $1 / 2$ & $0 / 7$ & $5 / 9$ & $0 / 2$ & $0 / 6$ & $0 / 9$ & $0 / 11$ & $2 / 3$ & $0 / 2$ & $8 / 51$ \\
aa 307-315 & $0 / 2$ & $0 / 7$ & $4 / 9$ & $0 / 2$ & $0 / 6$ & $0 / 9$ & $0 / 11$ & $0 / 3$ & $0 / 2$ & $4 / 51$ \\
aa 314-322 & $0 / 2$ & $5 / 7$ & $0 / 9$ & $0 / 2$ & $0 / 6$ & $0 / 9$ & $1 / 11$ & $0 / 3$ & $0 / 2$ & $6 / 51$ \\
\hline
\end{tabular}

$37^{\circ} \mathrm{C}$ in a humidified atmosphere of $5 \% \mathrm{CO}_{2}$ and $95 \%$ air. The cultures were pulsed $(4 \mathrm{~h})$ on day 6 with $1 \mu \mathrm{Ci}$ of $\left[{ }^{3} \mathrm{H}\right]$-thymidine (Amersham Life Science, Little Chalfont, UK) and harvested on filter mats with a Skatron harvester (Skatron Instruments, Oslo, Norway), and the radioactivity incorporated was measured by liquid scintillation counting and expressed as counts per minute (cpm). Average cpm were calculated from triplicate cultures stimulated with each antigen. The results were presented as stimulation index (SI), which is defined as follows: $\mathrm{SI}=\mathrm{cpm}$ in antigen-stimulated cultures/cpm in cultures without antigen. SI values $\geq 5$ and $\geq 2$ were considered positive proliferations in response to complex antigens and $\mathrm{Ag} 85 \mathrm{~B}$, respectively [20].

\section{Establishment and Testing of Antigen-Specific T-Cell Lines}

Antigen-specific T-cell lines were established from PBMC of all the patients after stimulation with $\mathrm{Ag} 85 \mathrm{~B}$ according to standard procedures [30]. In brief, PBMC $\left(2 \times 10^{5}\right.$ cells/well $)$ were stimulated with the antigen $(5 \mu \mathrm{g} / \mathrm{ml})$ in triplicate in 96-well plates and incubated at $37^{\circ} \mathrm{C}$ in an atmosphere of $5 \% \mathrm{CO}_{2}$ and $95 \%$ air. After 6 days, interleukin-2 (100 U/well; Amersham Life Sciences) was added twice a week until the cell culture density allowed transferring to 24-well tissue culture plates (Nunc). The growing T-cell lines were expanded in 24-well plates, with addition of interleukin-2 twice a week, until tested for antigen reactivity. The T-cell lines were tested for antigen- and peptide-induced proliferation in the presence of autologous APC using the procedures described previously [31]. The SI values were calculated as given above for PBMC, and $\mathrm{SI} \geq 2$ was considered a positive response [20].

\section{Results}

To predict HLA-DR binding regions of $\mathrm{Ag} 85 \mathrm{~B}$, the full-length sequence was analyzed using the ProPred server. This analysis revealed that the full-length protein could bind to all the $51(100 \%)$ alleles, the mature protein to 50 of the $51(98 \%)$ alleles and the secretory signal to 39 of the 51 (76\%) alleles of HLA-DR (data not shown). Further analysis of full-length protein, the signal peptide and mature $\mathrm{Ag} 85 \mathrm{~B}$ showed that 21, 3, and 18 peptide regions, respectively, were predicted to bind one or more alleles of HLA-DR (table 1). The predicted size of HLA-DR binding regions varied between 9 and 18 aa, but the majority $(66 \%)$ of the binding regions were $<12$ aa in length (table 1).

To determine the relevance of the predicted HLA-DR binding regions of $\mathrm{Ag} 85 \mathrm{~B}$ for recognition by $\mathrm{T}$ cells, a total of 31 peptides (18 mers, overlapping by 10 residues) covering the sequence of mature protein were analyzed for HLA-DR binding. The location (in relation to the fulllength protein), aa sequence and the HLA-DR binding prediction for each peptide are shown in figure 1 . The analysis revealed that 15 of the 31 peptides were predicted to be HLA-DR binders (fig. 1), which were evalu- 
Fig. 1. ProPred analysis of overlapping synthetic peptides covering the sequence of mature Ag85B for binding to HLA-DR alleles. The numbers of HLA-DR alleles predicted to bind/total numbers of HLA-DR alleles analyzed (percentages) by ProPred are shown. The amino acid sequences are numbered according to the sequence of fulllength Ag65B and the regions predicted to bind HLA-DR alleles are shown in bold face.

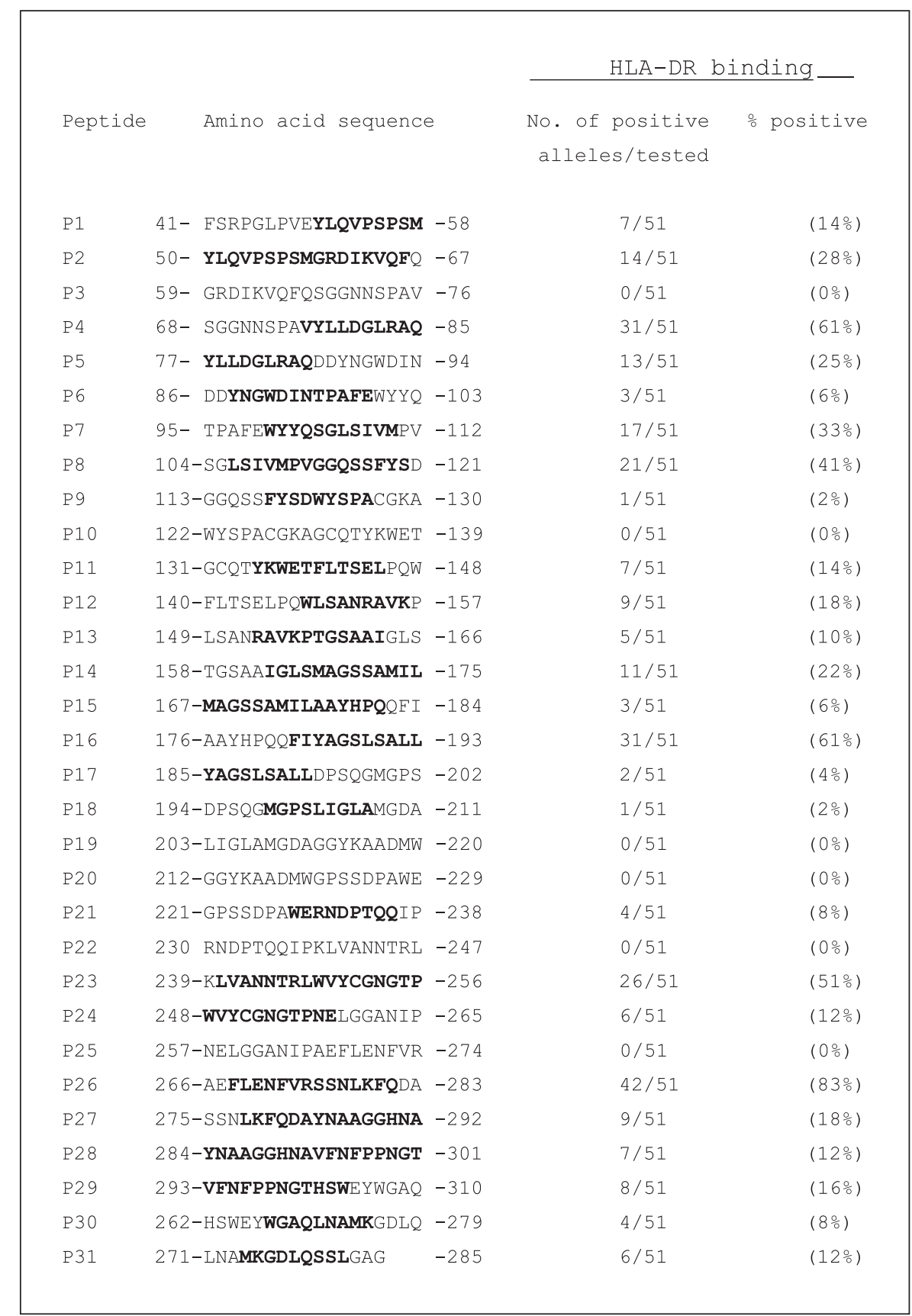

ated for T-cell reactivity with antigen-specific T-cell lines.

The T-cell lines were established from PBMC of $10 \mathrm{~TB}$ patients expressing HLA-DR1, -DR2, -DR4, -DR6, -DR7, -DR51, -DR52 and -DR53 molecules (table 2). PBMC from all of these patients responded in antigeninduced proliferation assays to complex antigens of $M$. tuberculosis, i.e. whole-cell, sonicate, culture filtrate and cell wall preparations (table 2). In addition, PBMC from 7 of the 10 patients responded to $\mathrm{Ag} 85 \mathrm{~B}$ in antigen-induced proliferation assays (table 2). Antigen-specific T-cell lines were established after stimulation of PBMC from each patient with Ag85B. When tested for reactivity to mature $\mathrm{Ag} 85 \mathrm{~B}$ and the synthetic peptides, all of the T-cell lines responded to $\mathrm{Ag} 85 \mathrm{~B}$ as well as to one or more of the peptides in antigen-induced proliferation assays (table 3 ). 
The results further showed that the T-cell epitopes were scattered throughout the sequence of $\mathrm{Ag} 85 \mathrm{~B}$, and variable numbers of peptides, ranging from 1 to 7 peptides, were recognized by each T-cell line (table 3 ). Interestingly, 14

Table 2. HLA-DR types and antigen-induced proliferation of PBMC obtained from TB patients

\begin{tabular}{|c|c|c|c|c|c|c|}
\hline \multirow{3}{*}{$\begin{array}{l}\mathrm{Pa}- \\
\text { tient }\end{array}$} & \multirow{3}{*}{$\begin{array}{l}\text { HLA-DR } \\
\text { type }\end{array}$} & \multicolumn{5}{|c|}{ Proliferation (SI) of PBMC in response to } \\
\hline & & \multicolumn{4}{|c|}{ complex $M$. tuberculosis antigens } & \multirow[t]{2}{*}{$\mathrm{Ag} 85 \mathrm{~B}$} \\
\hline & & whole cell & sonicat & $\mathrm{CF}$ & $\mathrm{CW}$ & \\
\hline 1 & $6,7,52,53$ & 331 & 42 & 190 & 452 & 82 \\
\hline 2 & 7,53 & ND & 17 & 19 & 35 & 113 \\
\hline 3 & 6,52 & 12 & 12 & 12 & 16 & 1.5 \\
\hline 4 & $6,7,52$ & 233 & 287 & 53 & 23 & 16 \\
\hline 5 & 2,51 & 12 & 10 & 6.7 & 12 & 2.1 \\
\hline 6 & 5,52 & 42 & 80 & 52 & 73 & 11 \\
\hline 7 & $1,4,53$ & 134 & 108 & 25 & 122 & 6.8 \\
\hline 8 & $2,7,51$ & 35 & 30 & 30 & 31 & 3.2 \\
\hline 9 & 2,51 & 272 & 157 & 268 & 199 & 29 \\
\hline 10 & $2,6,51,52$ & 19 & 26 & 23 & 20 & 1.5 \\
\hline \multicolumn{2}{|c|}{ n positive/n tested } & $9 / 10$ & $10 / 10$ & $10 / 10$ & $10 / 10$ & $8 / 10$ \\
\hline
\end{tabular}

The positive SI values, as defined in the Materials and Methods, are given in bold face. $\mathrm{ND}=$ Not determined; $\mathrm{CF}=$ culture filtrate; $\mathrm{CW}=$ cell walls. of the 15 peptides predicted to be HLA-DR binders were shown to have T-cell epitopes as one or more T-cell lines responded to these peptides in proliferation assays (table 3 ).

\section{Discussion}

The mycolyl transferase $85 \mathrm{~B}$ of $M$. tuberculosis is a 30 $\mathrm{kDa}$ secreted protein and has also been referred in the published literature as antigen 85-B (Ag85B), extracellular $\alpha$-antigen, fibronectin-binding protein B and MPT59 [32]. The full-length $\mathrm{Ag} 85 \mathrm{~B}$ is a secreted protein of $325 \mathrm{aa}$, and the cleavage of 40 aa signal peptide from the amino terminus yields the mature protein of 285 aa [32]. It is a major antigenic protein of $M$. tuberculosis and is among one of the new vaccine candidates against TB [3]. The HLA-DR binding analysis of Ag85B using the ProPred server showed that the full-length protein, signal peptide and the mature protein could bind to 100, 76 and 98\% alleles of HLA-DR, respectively. These observations reinforce the promiscuous nature of $\mathrm{Ag} 85 \mathrm{~B}$ for presentation to $\mathrm{T}$ cells and thus support the use of this protein in vaccine applications.

Further analysis with ProPred showed that there are 21 peptide regions in full-length $\mathrm{Ag} 85 \mathrm{~B}$, which can bind

Table 3. Antigen-/peptide-induced proliferation of Ag85B-specific T-cell lines established from PBMC of TB patients in response to Ag85B and the peptides predicted to bind HLA-DR alleles

\begin{tabular}{|c|c|c|c|c|c|c|c|c|c|c|c|}
\hline \multirow{2}{*}{$\begin{array}{l}\text { Antigen/ } \\
\text { peptide }\end{array}$} & \multicolumn{11}{|c|}{ Antigen-/peptide-induced proliferation (SI) of T-cell lines from patient No. } \\
\hline & 1 & 2 & 3 & 4 & 5 & 6 & 7 & 8 & 9 & 10 & $\mathrm{P} / \mathrm{T}$ \\
\hline Ag85B & 37 & 13 & 22 & 18 & 5.0 & 47 & 30 & 239 & 16 & 49 & $10 / 10$ \\
\hline $\mathrm{P} 1$ & 1.3 & 3.0 & 2.7 & 1.3 & 1.3 & 1.1 & 1.7 & 1.3 & 1.7 & 1.5 & $2 / 10$ \\
\hline P2 & 1.2 & 3.6 & 3.7 & 1.4 & 1.2 & 1.9 & 1.0 & 0.9 & 1.5 & 1.2 & $2 / 10$ \\
\hline P4 & 2.1 & 14 & 1.3 & 1.2 & 1.2 & 0.9 & 5.8 & 1.3 & 2.6 & 2.3 & $5 / 10$ \\
\hline P7 & 1.5 & 2.8 & 2.4 & 1.2 & 1.2 & 1.2 & 1.5 & 1.3 & 3.4 & 1.8 & $3 / 10$ \\
\hline P8 & 1.1 & 2.5 & 2.1 & 1.1 & 1.2 & 0.9 & 1.4 & 1.0 & 1.5 & 1.6 & $2 / 10$ \\
\hline P11 & 1.6 & 1.5 & 1.3 & 1.4 & 9.8 & 53 & 1.2 & 0.9 & 3.4 & 1.6 & $3 / 10$ \\
\hline P12 & 1.3 & 1.4 & 2.1 & 1.1 & 1.1 & 1.3 & 1.2 & 1.1 & 1.6 & 1.3 & $1 / 10$ \\
\hline P13 & 7.8 & 1.7 & 1.9 & 1.7 & 1.1 & 1.4 & 1.3 & 41 & 1.2 & 1.1 & $2 / 10$ \\
\hline P14 & 2.2 & 2.5 & 1.8 & 1.0 & 1.2 & 1.0 & 1.3 & 1.1 & 1.8 & 1.4 & $2 / 10$ \\
\hline P16 & 1.3 & 13 & 28 & 6.1 & 1.7 & 1.1 & 1.4 & 115 & 1.6 & 1.7 & $4 / 10$ \\
\hline P23 & 2.2 & 1.6 & 1.3 & 1.2 & 1.4 & 8.5 & 1.3 & 1.7 & 1.6 & 1.6 & $2 / 10$ \\
\hline P26 & 0.7 & 1.4 & 1.9 & 4.3 & 1.1 & 0.7 & 1.5 & 31 & 1.9 & 1.9 & $2 / 10$ \\
\hline P29 & 0.9 & 1.1 & 1.1 & 1.4 & 1.0 & 1.0 & 2.7 & 1.7 & 1.3 & 1.5 & $1 / 10$ \\
\hline P30 & 0.7 & 0.6 & 1.1 & 1.1 & 1.1 & 2.3 & 1.4 & 1.0 & 5.6 & 1.2 & $2 / 10$ \\
\hline P31 & 1.5 & 1.1 & 0.9 & 1.2 & 1.5 & 0.9 & 1.4 & 1.6 & 1.5 & 0.9 & $1 / 10$ \\
\hline
\end{tabular}

The positive SI values, as defined in the Materials and Methods, are given in bold face. 
to HLA-DR alleles. Interestingly, three of the 21 HLADR binding regions belong to the signal sequence of 40 aa and the remaining 18 regions belong to the mature protein sequence of 285 aa (table 1). In agreement with these data predicting the presence of HLA-DR binding regions in the signal sequence, T-cell reactivity to the signal peptide sequence has been reported previously [33].

To experimentally verify the usefulness of ProPred analysis for presentation of $\mathrm{Ag} 85 \mathrm{~B}$ and its peptides to $\mathrm{T}$ cells, antigen-specific T-cell lines were established from PBMC of a group of 10 HLA-DR-heterogeneous TB patients. In all of the patients, PBMC responded to the complex antigens of $M$. tuberculosis, showing that their T-cell responses were not suppressed due to the disease status. In addition, PBMC from 7 of the 10 patients responded to $\mathrm{Ag} 85 \mathrm{~B}$, confirming that it is a major T-cell antigen of M. tuberculosis. However, when Ag85B-specific T-cell lines were established from the same patients and tested for reactivity to $\mathrm{Ag} 85 \mathrm{~B}$ in antigen-induced proliferation assays, all of the T-cell lines responded to this antigen. These results suggest that Ag85B-reactive $\mathrm{T}$ cells were present in PBMC of all the patients, but their frequency was below the detectable level in 3 patients. The stimulation with Ag85B during T-cell establishment enriched Ag85B-reactive cells, and therefore, all the T-cell lines responded to $\mathrm{Ag} 85 \mathrm{~B}$. This phenomenon has previously been observed with some other mycobacterial antigens as well [9]. Since the T-cell lines were established from a HLA-DR-heterogeneous group of patients, the positive response of all the T-cell lines to Ag85B confirms its promiscuous presentation to $\mathrm{T}$ cells.

The T-cell lines were also tested for reactivity to 15 peptides from an overlapping series of 31 peptides covering the sequence of $\mathrm{Ag} 85 \mathrm{~B}$ [18]. The tested peptides were predicted to bind HLA-DR alleles by ProPred analysis (fig. 1). Each peptide of the overlapping series was 18 aa in length and overlapped with the neighboring peptides by 9 aa (fig. 1). This peptide design is in accordance with the observation that the length of the predicted HLA-DR binding regions of $\mathrm{Ag} 85 \mathrm{~B}$ varied between 9 and 18 aa (table 1). The results also showed that 14 of the 15 peptides, considered as HLA-DR binders by ProPred analysis, were recognized by one or more T-cell lines in proliferation assays (table 3 ). The primary sequence of aa residues in a peptide is important for HLA-DR binding, and thus for T-cell recognition, and not the aa composition of the peptide, because the major contact points have specific aa, i.e. an aromatic or hydrophobic residue at the amino terminus and three additional hydrophobic resi- dues in the middle portion and the carboxy-terminal end of the peptide [34].

Previous studies have shown that bioinformatics tools, such as TEPITOPE and ProPred, are useful to identify HLA-DR ligands derived from tumors and endogenous proteins involved in autoimmune diseases $[35,36]$. In addition, these tools have also been shown to identify immunogenic peptides of mycobacterial proteins such as Mce proteins, LppX and ESAT6 [20, 21, 37]. Our study using the peptides of $\mathrm{Ag} 85 \mathrm{~B}$ further confirms these observations.

\section{Conclusion}

This study demonstrated that peptides capable of $\mathrm{T}$ cell reactivity in HLA-heterogeneous populations can be predicted from the HLA-DR binding analysis of complete proteins. Compared to the overlapping synthetic peptide approach to identify T-cell epitopes, a pre-screening for HLA-DR binding predictions will reduce the cost of synthesizing peptides by reducing the number of peptides required for actual experimental evaluation for Tcell reactivity.

\section{Acknowledgment}

This study was supported by Kuwait University Research Administration grant MI114 and the College of Graduate Studies, Kuwait University, Kuwait. 


\section{References}

-1 Frieden TR, Sterling TR, Munsiff SS, Watt CJ, Dye C: Tuberculosis. Lancet 2003;362:887899.

-2 Behbehani N, Abal A, Al-Shami A, Enarson, DA: Epidemiology of tuberculosis in Kuwait from 1965 to 1999 . Int $\mathrm{J}$ Tuberc Lung Dis 2002;6:465-469.

$\checkmark 3$ Mustafa AS: Biotechnology in the development of new vaccines and diagnostic reagents against tuberculosis. Curr Pharm Biotechnol 2001;2:157-173.

$\checkmark 4$ Mustafa AS: Development of new vaccines and diagnostic reagents against tuberculosis. Mol Immunol 2002;39:113-119.

5 Mustafa AS, Al-Attiyah R: Looking beyond BCG vaccines. J Postgrad Med 2003;49:143140.

6 Ahmad S, Amoudy HA, Thole JE, Young DB, Mustafa AS: Identification of a novel protein antigen encoded by a Mycobacterium tuberculosis-specific RD1 region gene. Scand J Immunol 1999;49:515-522.

7 Ahmad S, Ali MM, Mustafa AS: Construction of a modified vector for efficient purification of recombinant Mycobacterium tuberculosis proteins expressed in Escherichia coli. Protein Expr Purif 2003;29:167-175.

-8 Mustafa AS, Lundin KE, Meloen RH, Shinnick TM, Oftung F: Identification of promiscuous epitopes from the mycobacterial 65-kilodalton heat shock protein recognized by human CD4(+) T cells of the Mycobacterium leprae memory repertoire. Infect Immun 1999;67: 5683-5689.

$\checkmark 9$ Mustafa AS: Identification of T-cell-activating recombinant antigens shared among three candidate antileprosy vaccines, killed $M$. leprae, M. bovis BCG, and Mycobacterium w. Int $\mathbf{J}$ Lepr Other Mycobact Dis 1988;56:265-273.

$\checkmark 10$ Haanen JB, Ottenhoff TH, Lai A, Fat RF, Soebono H, Spits H, de Vries RR: Mycobacterium leprae-specific $\mathrm{T}$ cells from a tuberculoid leprosy patient suppress HLA-DR3-restricted T cell responses to an immunodominant epitope on $65-\mathrm{kDa}$ hsp of mycobacteria. J Immunol 1990;145:3898-3904

$>11$ Oftung F, Lundin KEA, Geluk A, Shinnick TM, Meloen R, Mustafa AS: Primary structure and $\mathrm{MHC}$ restriction of peptide defined $\mathrm{T}$ cell epitopes from recombinantly expressed mycobacterial protein antigens. Med Princ Pract 1997;6:66-73.

12 Ravn P, Demissie A, Eguale T, Wondwosson H, Lein D, Amoudy HA, Mustafa AS, Jensen AK, Holm A, Rosenkrands I, Oftung F, Olobo J, von Reyn F, Andersen P: Human T cell responses to the ESAT-6 antigen from Mycobacterium tuberculosis. J Infect Dis 1999;179: 637-645.

13 Arend SM, van Meijgaarden KE, de Boer K, de Palou EC, van Soolingen D, Ottenhoff TH, van Dissel JT: Tuberculin skin testing and in vitro T cell responses to ESAT- 6 and culture filtrate protein 10 after infection with $\mathrm{Myco}$ bacterium marinum or $M$. kansasii. J Infect Dis 2002; 186:1797-1807.
14 Arend SM, Geluk A, van Meijgaarden KE, van Dissel JT, Theisen M, Andersen P, Ottenhoff TH: Antigenic equivalence of human T-cell responses to Mycobacterium tuberculosis-specific RD1-encoded protein antigens ESAT-6 and culture filtrate protein 10 and to mixtures of synthetic peptides. Infect Immun 2000;68: 3314-3321.

15 Mustafa AS, Cockle PJ, Shaban F, Hewinson RG, Vordermeier HM: Immunogenicity of Mycobacterium tuberculosis RD1 region gene products in infected cattle. Clin Exp Immunol 2002; 130:37-42.

16 Vordermeier HM, Whelan A, Cockle PJ, Farrant L, Palmer N, Hewinson RG: Use of synthetic peptides derived from the antigens ESAT-6 and CFP-10 for differential diagnosis of bovine tuberculosis in cattle. Clin Diagn Lab Immunol 2001;8:571-578.

17 Olsen AW, Hansen PR, Holm A, Andersen P: Efficient protection against Mycobacterium tuberculosis by vaccination with a single subdominant epitope from the ESAT-6 antigen. Eur J Immunol 2000;30:1724-1732.

18 Mustafa AS, Shaban FA, Abal AT, Al-Attiyah R, Wiker HG, Lundin KE, Oftung F, Huygen $\mathrm{K}$ : Identification and HLA restriction of naturally derived Th1-cell epitopes from the secreted Mycobacterium tuberculosis antigen 85B recognized by antigen-specific human CD4(+) T-cell lines. Infect Immun 2000;68:39333940.

19 Al-Attiyah R, Shaban FA, Wiker HG, Oftung F, Mustafa AS: Synthetic peptides identify promiscuous human Th1 cell epitopes of the secreted mycobacterial antigen MPB70. Infect Immun 2003;71:1953-1960.

20 Al-Attiyah R, Mustafa AS: Computer-assisted prediction of HLA-DR binding and experimental analysis for human promiscuous Th1 cell epitopes in a novel 24-kDa secreted lipoprotein (LppX) of Mycobacterium tuberculosis. Scand J Immunol 2004;59:16-24.

21 Panigada M, Sturniolo T, Besozzi G, Boccieri MG, Sinigaglia F, Grassi GG, Grassi F: Identification of a promiscuous $\mathrm{T}$-cell epitope in Mycobacterium tuberculosis Mce proteins. Infect Immun 2002;70:79-85.

22 Feller DC, de la Cruz VF: Identifying antigenic T cell sites. Nature 1991;349:720-721.

23 De Groot AS, Jesdale B, Szu E, Schafer JR Chics RM, Deocampo G: An interactive Web site providing major histocompatibility ligand predictions: Application to HIV research. AIDS Res Hum Retroviruses 1997;13:529_ 531 .

-24 Hammer J, Bono E, Gallazzi F, Belunis C, Nagy Z, Sinigaglia F: Precise prediction of major histocompatibility complex class-II peptide interaction based on peptide side chain scanning. J Exp Med 1994; 180:2353-2358

25 Sturniolo T, Bono E, Ding J, Raddrizzani L, Tuereci O, Sahin M, Braxenthaler F, Gazzali F, Protti MP, Sinigaglia F, Hammer J: Generation of tissue-specific and promiscuous HLA ligand databases using DNA microarrays and virtual HLA class II matrices. Nat Biotechnol 1999; 17:555-561.
26 Singh H, Raghava GPS: ProPred: Prediction of HLA-DR binding sites. Bioinformatics 2001; 17:1236-1237.

-27 Mustafa AS, Amoudy HA, Wiker HG, Abal AT, Ravn P, Oftung F, Andersen P: Comparison of antigen-specific T-cell responses of tuberculosis patients using complex or single antigens of Mycobacterium tuberculosis. Scand J Immunol 1998;48:535-543.

28 Mustafa AS, Shaban FA, Al-Attiyah R, Abal AT, El-Shamy AM, Andersen P, Oftung F: Human Th1 cell lines recognize the Mycobacterium tuberculosis ESAT-6 antigen and its peptides in association with frequently expressed HLA class II molecules. Scand J Immunol 2003;57:125-134.

29 Al-Attiyah R, Mustafa AS, Abal AT, Madi NM, Andersen P: Restoration of mycobacterial antigen-induced proliferation and interferon-gamma responses in peripheral blood mononuclear cells of tuberculosis patients upon effective chemotherapy. FEMS Immunol Med Microbiol 2003;38:249-256.

30 Mustafa AS, Oftung F, Amoudy HA, Madi NM, Abal AT, Shaban F, Rosen Krands I, Andersen P: Multiple epitopes from the Mycobacterium tuberculosis ESAT-6 antigen are recognized by antigen-specific human $\mathrm{T}$ cell lines. Clin Infect Dis 2000;30(suppl 3):S201-S205.

-31 Mustafa AS, Lundin KE, Oftung F: Isolation of recombinant phage clones expressing mycobacterial $\mathrm{T}$ cell antigens by screening a recombinant DNA library with human CD4+ Th1 clones. FEMS Immunol Med Microbiol 1998; 22:205-216.

32 Tuberculist Web Server. http://genolist.pasteur.fr/TubercuList.

33 Silver RF, Wallis RS, Ellner JJ: Mapping of T cell epitopes of the $30-\mathrm{kDa}$ alpha antigen of Mycobacterium bovis strain bacillus CalmetteGuérin in purified protein derivative (PPD)positive individuals. J Immunol 1995; 154: 4665-4674.

34 Goldsby RA, Kindt TJ, Osborne BA: Kuby Immunology, ed 4. New York, Freeman, 2000 p 186.

35 Hammer J, Sturniolo T, Sinigaglia F: HLA class II peptide binding specificity and autoimmunity. Adv Immunol 1997;66:67-100.

-36 Manici S, Sturniolo T, Imro MA, Hammer J, Sinigaglia F, Noppen C, Spagnoli G, Mazzi B Bellone M, Dellabona P, Protti MP: Melanoma cells present a MAGE-3 epitope to CD4+ cytotoxic $\mathrm{T}$ cells in association with histocompatibility leukocyte antigen DR11. J Exp Med 1999; 189:871-876.

37 Vordermeier M, Whelan AO, Hewinson RG: Recognition of mycobacterial epitopes by $\mathrm{T}$ cells across mammalian species and use of a program that predicts human HLA-DR binding peptides to predict bovine epitopes. Infect Immun 2003;71:1980-1987. 